\title{
Islamic Education dalam Perspektif Ekonom dan Filosof (Analisis Paradigma Pendidikan Barat Dan Timur)
}

\author{
NURHADI \\ STAI Al-Azhar Pekanbaru \\ Jl. Cipta Karya Kel. Sialang Munggu Kec. Tampan Pekanbaru Riau \\ Email: alhadicentre@yahoo.co.id
}

\begin{abstract}
Education is an agent of social change, culture, economy and reasoning of thought and human character. Islamic education as an atmosphere of modernization and globalization is required to play a dynamic, elastic and proactive role on a regular basis. Its existence is expected to bring the values of change and contribute to the benefit of the ummah. But nowadays education is often used for social mobilization, politics and economy so that giving birth to intellectual materialistic economical. The research method uses qualitative descriptive concept, with research type of library of Risert (bibliography), data collection method using primary and secondary data and technical data analysis using contents analysis method. From the study conducted found that Islamic education perspective of economists teaches the importance of welfare in life, which is obtained by preparing science in education. While Islamic education philosophers perspective teaches the importance of moral and moral values with the aim to get closer to God, so that Islamic education prepares scientists who are intelligent religious knowledge, faith and heart.
\end{abstract}

Keywords: Islamic, Education, Perspectives, Economist, Philosopher

\begin{abstract}
Abstrak: Pendidikan adalah agen perubahan sosial, budaya, ekonomi dan nalar pikir serta karakter manusia. Pendidikan Islam sebagai atmosfir modernisasi dan globalisasi dituntut mampu berperan dinamis, elastis dan proaktif secara berkala. Keberadaanya diharapkan bisa membawa nilai-nilai perubahan dan berkontribusi bagi kemaslahatan umat. Namun saat ini pendidikan sering diperalat untuk sarana mobilisasi sosial, politik dan ekonomi sehingga melahirkan intelektual yang materialistis ekonomis. Adapun metode Penelitian ini menggunakan konsep deskriptif kualitatif, dengan jenis penelitian library Risert (kepustakaan), metode pengumpulan datanya menggunakan data primer dan sekunder dan teknis analisis datanya memakai metode konten analisis. Dari kajian yang dilakukan ditemukan bahwa pendidikan Islam perspektif ekonom mengajarkan pentingnya kesejahteraan dalam hidup, yang mana hal tersebut diperoleh dengan cara mempersiapkan ilmu pengetahuan dalam pendidikan. Sedangkan pendidikan Islam perspektif filosof mengajarkan pentingnya nilai-nilai akhlak dan moral dengan tujuan untuk mendekatkan diri kepada Allah, sehingga pendidikan Islam mempersiapkan ilmuan-ilmuan yang religi cerdas ilmu, iman dan hati.
\end{abstract}

Kata Kunci: Islamic, Education, Perspektif, Ekonom, Filosof 


\section{PENDAHULUAN}

Pendidikan adalah sektor vital bagi kehidupan manusia dari mulai alam kandungan sampai alam barzah. Pendidikan adalah teori yang fundamental dalam mencetak manusia yang berkarakter akhlak mulia (Depdiknas, 2001: 263). Budi pekerti, ahklak dan karakter kepribadiannya tidak terlepas dari pendidikan yang didapat dari lingkungan keluarga dan sosial tempat hidup bermasyarakat (Hadari, 1982: 10). Lingkungan keluarga sangat mendominasi dalam perkara ini (Raja, 2001: 11). Seorang yang tumbuh dan berkembang dalam lingkungan keluarga yang religi, otomatis akan melahirkan insan yang berkarakter religi (beriman dan bertaqwa) (UU RI, 2004: 23). Sebagaimana Allah mengajarkan kepada Nabi Muhammad saw melalui Jibril nilianilai religi ketauhidan yang termaktub dalam surah al-Alaq ayat 1-5 sebagi berikut:

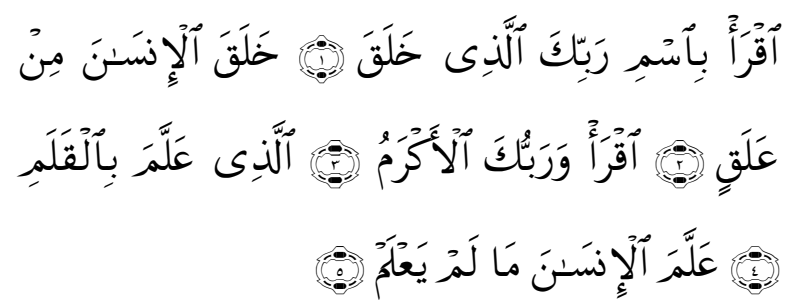

Artinya: Bacalah dengan (menyebut) nama Tuhanmu yang Menciptakan. Dia Telah menciptakan manusia dari segumpal darah. Bacalah, dan Tuhanmulah yang Maha pemurah. Yang mengajar (manusia) dengan perantaran kalam. Dia mengajar kepada manusia apa yang tidak diketahuinya (Depag RI, 2005: 1079) .

Ayat diatas menjelaskan secara sederhana pendidikan Islam. Diawali dari membaca, mengenal diri, mengenal tuhanya yang maha mengetahui dan pentingnya pendidikan Islam dalam kehidupan dunia untuk mencapai kebahagiaan akhirat. Menurut Qurais Shihab, ada 2 poin kandungan surah alAlaq ayat 1-5 : 1). Urgensi belajar menurut Muhammad Quraish Shihab pada surat al'Alaq ayat 1-5 kewajiban paling utama manusia yaitu untuk menuntut ilmu, karena derajat orang-orang yang berilmu tentu lebih tinggi dibanding dengan orang yang tidak memiliki ilmu. Oleh karena itu belajar sangatlah penting untuk kelangsungan hidup manusia sebagai hamba-Nya dan khalifah di dunia ini. 2). Implikasi belajar dalam surat al-'Alaq 15terhadap metode pendidikan Islam bahwa dengan menggunakan metode keteladanan, metode pengulangan, metode cerita, metode dialog dan metode himbauan itu dapat diterapkan pada setiap proses belajar Implikasinya terdapat dalam setiap teladan hendaknya selalu memuat sikap kemuliaan dan kebaikan budi yang dimiliki oleh peserta didik (Quraish, 2011: 1 dan Edwar, 2014: IX).

Islam di samping memerintahkan umatnya untuk belajar, menggali ilmu pengetahuan, juga memberikan penghargaan yang sangat istimewa bagi orang yang selalu belajar, menuntut ilmu dan mengembangkan dirinya. Banyak sekali keterangan dalam al-Qur'an dan alSunnah yang mengisyaratkan tentang martabat orang berilmu, kedudukan para ulama, dan keutamaan belajar. Di antaranya firman Allah swt yang dalam surah al-Mujadalah ayat 11 :

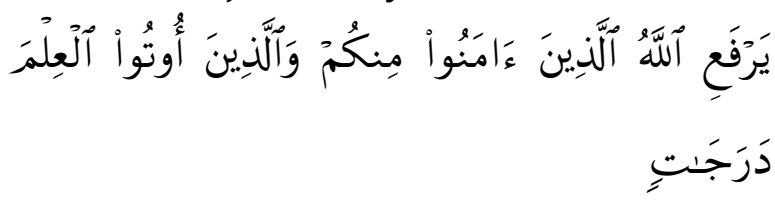

Artinya: Allah akan meninggikan orangorang yang beriman di antaramu dan orang-orang yang diberi ilmu pengetahuan beberapa derajat (Depag RI, 2005: 910).

Pendidikan adalah agen perubahan sosial, budaya, ekonomi dan nalar pikir serta karakter manusia. Pendidikan Islam sebagai atmosfir modernisasi dan globalisasi dituntut mampu berperan selalu dinamis, elastis dan proaktif secara berkala (Hasan, 1988: 86). Keberadaanya diharapkan bisa membawa nilai-nilai perubahan dan berkontribusi bagi kemaslahatan umat Islam, baik dari 
tataran intelektual teoritis maupun intelektual praktis (Zakiah, 1992: 28). Pendidikan Islam tidak hanya sekadar metode menanamkan nilai akhlak dan moral dalam membentengi pribadi dari ekses negatif globalisasi dan modrenisasi. Namun yang terpenting adalah bagaimana subtnasi akhlak dan moral yang ada dalam pendidikan Islam mampu menjadi kekuatan sebagai pembebas (liberating force) dari himpitan kemiskinan, kebodohan dan keterbelakangan sosial budaya dan ekonomi (Ahmad, 1994: 77).

Era Globalisasi berpendapat bahwa dunia selalu didominasi oleh perekonomian dan munculnya hegemoni pasar bebas dalam bingkai dunia kapitalis dan ideologi neoliberalis. Dalam rangka mengimbangi arus deras era globalisasi dan modrenisasi perlu adanya pengembangan dan perencanaan menanamkan akhlak dan budi pekerti yang berkarakter nasionalisme agar dapat menghadapi dampak negatif dari perubahan zaman (Syaiful, 2000: 37).

Pelanggaran terhadap kesepakatan dan peraturan dalam dunia pendidikan tidak dapat dikatakan jarang bahkan terlalu sering. Sehingga kesempatan untuk mendapatkan pendidikan tidak diperoleh, pendidikan berorientasi gelar dan pangkat serta strata sosial ekonomi bukan keilmuan dan kearifan, hal ini menimbulkan kriminalitas di dunia pendidikan (Max Weber dalam Mimbar 1999: 164-166). Ancaman ini cukup serius dan harus disikapi agar tidak melanda pendidikan Islam (Wan Daud, 2003: 166).

Sangat ironis, idiologi materialistis selalu masuk dalam lembaga pendidikan Islam, sehingga menjadi kesan bahwa belajar agama sangat mahal, lalu kebanyakan masyarakat tidak sangggup mengakses nilai-nilai religi agama yang sebenarnya (Hasan, 1992: 120). Apalagi lembaga pendidikan Islam yang melekat label favorit dan bergengsi, hanya orang yang tajir (berkantong tebal) dan yang cerdas pikiran akal dapat memasukinya.
Dan yang sangat miris lagi, bahwa pendidikan hanya diperalat untuk sarana mobilisasi sosial, politik dan ekonomi. Dominasi pemikiran seperti ini di dunia pendidikan telah melahirkan idiologi patologi psiko-sosial, terutama dikalangan peserta didik dan orang tuanya, Wan Daud menyebutnya dengan penyakit gelar (diploma disease), yaitu usaha dalam meraih suatu gelar pendidikan bukan karena kepentingan ilmu dan pendidikan melainkan karena nilai-nilai ekonomi, politik dan sosial (Wan Daud, 2003: 166). Orientasi diatas melahirkan intelektual yang materialistis ekonomis, sekaligus menapikan ilmuan yang filosofis religis agamis. Keilmuan tanpa gelar tidak diakui, gelar tanpa ekonomi dipandang sebelah mata. Kesuksesan seorang ilmuan dan sarjanawan diukur dengan materi dan ekonomi bukan pada tataran kontruksi berpikir yang logis, ilmiyah dan dinamis praktis (Rachmat, 1996: 26). Maka hal inilah yang menjadi dasar perlunya nilainilai filosofis dalam dunia pendidikan Islam, agar jiwa dan nalar pikiran yang menerima ilmu pengetahuan tidak kosong dengan nilai-nilai ketauhidan dan hakikat diri. Sebenarnya secara sederhana masalah ini dapat dijawab dengan dua paradigm kelimuan, yaitu paradigma intelektual keilmuan barat sebagai tonggak idiologi materialis, dan paradigm intelektual timur (timur tengah) sebagai struktur berpikir pilosofis religis agamis (Abuddin, 2001: 206).

\section{KAJIAN TEORITIS Teori Pendidikan}

Kata pendidikan dalam bahasa Indonesia berasal dari kata didik, dalam kamus Besar Bahasa Indonesia diartikan perbuatan (hal, cara dan sebagainya) mendidik (Depdikbud, 1991: 323), pengertian tersebut dapat dipahami bahwa kata pendidikan adalah cara mendidik. Kata lain yang semakna dalam bahasa Indonesia ada kata pengajaran, cara mengajar atau mengajarkan, kata lain 
yang serumpun adalah mengajar yang berarti memberi pengetahuan (Poerwardarminta, 1991: 250).

Menurut Ki Hadjar Dewantara pendidikan adalah daya-upaya untuk memajukan bertumbuhnya budi pekerti (kekuatan batin, karakter), pikiran (intelek) dan tubuh anak, dalam rangka kesempurnaan hidup dan keselarasan dengan dunianya (Ki Hadjar, 1962: 14-15 dan Bartolomeus, 2010: 28). Beliau tokoh pemikir dan praktisi pendidikan, beliau disebut sebagai pejuang kemanusiaan dalam pendidikan di Indonesia. Hal ini terlihat bagaimana upayanya dalam membangun dan menyelenggarakan pendidikan di Indonesia dengan teori dan konsep, serta landasan juga semboyan yaitu metode menampilkan cirri khas kultural budaya Indonesia. Dilakukannya hanya untuk mewujudkan idealisme yakni membangun kesadaran manusia akan hak-haknya dalam menerima pendidikan (Bartolomeus: 58). Pendidikan itu membentuk manusia yang berbudi pekerti, berpikiran (pintar, cerdas) dan bertubuh sehat (Sindhunata, 1999: 19 dan Bartolomeus: 28). Beliau juga dijuluki Bapak Pendidikan Nasional Indonesia. Baginya, pendidikan adalah upaya untuk membangun kesadaran eksistensial akal manusia. Akal bermuatan filosofis dari konsep kontruksi berpikir, landasanlandasan teori, semboyan dan metode pendidikan yang dikembangkan sangat universal (Bartolomeus: 58). Praktek pendidikan diproyeksikannya lebih ke arah pembangunan kemanusiaan secara utuh, Pendidikan adalah upaya mengembangkan seluruh aspek pribadi peserta didik, yaitu iman dan takwa kepada Tuhan, budi pekerti yang luhur, penguasaan keterampilan, kesehatan jasmani dan rohani, kepribadian yang mantap dan mandiri, mempunyai rasa tanggungjawab kemasyarakatan dan kebangsaan (H.A.R. Tilaar, 1999: 137-138 dan Bartolomeus: 4), berdasarkan asasasas (landasan-landasan) pendidikannya yang dikenal dengan Pancadharma, Pancadharma terdiri dari asas kodrat alam (hakikat manusia adalah bagian dari alam semesta), kemerdekaan (kehidupan hendaknya sarat dengan kebahagiaan dan kedamaian), kebangsaan (seseorang harus merasa satu dengan bangsanya dan di dalam rasa kesatuan tersebut tidak boleh bertentangan dengan rasa kemanusiaan), kebudayaan (manusia adalah makhluk berbudaya), dan kemanusiaan (pentingnya persahabatan dengan bangsabangsa lain) (H.A.R. Tilaar, 1999: 132 dan Danasaputra, 1876: 174-176), Susunan asas-asas pendidikan dalam penelitian ini disesuaikan dengan susunan yang terdapat dalam buku Nursid Sumaatmadja (Nursid, 2002: 69-75 dan Bartolomeus: 37), dan semboyan serta metode pendidikan yang bersifat "mengasuh", Dalam praksisnya, konsep, semboyan dan metode pendidikan diterapkan berdasarkan hidup kekeluargaan untuk mempersatukan pengajaran pengetahuan dan pengajaran budi pekerti (Ki Hadjar,1954: 44-46). Pada tahun 1952, kurikulum pendidikan dikenal dengan nama Rentjana Pelajaran Terurai 1952. Kurikulum ini sudah mengarah pada suatu system pendidikan nasional. Yang paling menonjol dan sekaligus ciri dari kurikulum 1952 ini bahwa setiap rencana pelajaran harus memperhatikan isi pelajaran yang dihubungkan dengan kehidupan sehari-hari. Di sini jelas sekali bahwa pendidikan di sekolah bertolak dari pengalaman eksistensial (Bartolomeus: 59). Asas-asas pendidikan yang diterapkan sagat selaras dengan Tujuan Pendidikan Nasional sebagaimana dalam Undang-Undang No. 4 Tahun 1950 tentang Dasar-Dasar Pendidikan dan Pengajaran di Sekolah untuk seluruh Indonesia, Undang-Undang ini dipersiapkan pada masa revolusi namun baru dapat diundangkan pada tahun 1950 dan masih terbatas di lingkungan apa yang disebut Republik Yogya (H.A.R. Tilaar, 1999: 134). Undang-Undang No. 4 
Tahun 1950 ini kemudian diubah menjadi Undang-Undang No. 12 Tahun 1954 yang berlaku untuk seluruh daerah Republik Indonesia, pada masa ini kurikulum pendidikan yang berlaku dikenal dengan nama Rencana Pelajaran Terurai 1952. Kurikulum ini sudah mengarah pada suatu sistem pendidikan nasional. Yang paling menonjol dan sekaligus ciri dari kurikulum 1952 ini bahwa setiap rencana pelajaran harus memperhatikan isi pelajaran yang dihubungkan dengan kehidupan sehari-hari. Di sini jelas sekali bahwa pendidikan di sekolah bertolak dari pengalaman eksistensial (Bartolomeus: 59). Pasal 3 UndangUndang No. 12 Tahun 1954 ini dengan jelas menunjukkan tujuan pendidikan dan pengajaran nasional ialah "membentuk manusia susila yang cakap dan warga negara yang demokratis serta bertanggung jawab tentang kesejahteraan masyarakat dan tanah air" (Bartolomeus: 60).

Menurut bapak pendidikan nasional, pendidikan harus menerapkan tiga unsur utama pendidikan dan pengajaran berdasarkan kurikulum nasional yang berlaku, yakni: Pertama, membentuk manusia susila yang cakap. Kedua, membentuk warga negara yang demokratis. Ketiga, membentuk manusia yang bertanggungjawab tentang kesejahteraan masyarakat dan tanah air. Jadi pada saat beliau menjabat sebagai Mentri Pendidikan dan Kebudayaan Nasional, pendidikan di sekolah bukan hanya menjadikan manusia menjadi cakap, tetapi manusia susila dan cakap, menghasilkan warga Negara yang demokratis dan bertanggungjawab atas kesejahteraan masyarakat dan tanah air Indonesia (Bartolomeus: 60).

\section{Teori Pendidikan Islam}

Pendidikan Islam secara terminologi menurut Zakiyah Darajat adalah sikap pembentukan manusia agar mengalami perubahan sikap dan tingkah laku yang sesuai dengan petunjuk agama Islam (Zakiyah, 1992: 25). Sedangkan menurut Abdul Mujib adalah proses transinternalisasi pengetahuan dan nilai Islam kepada orang lain melalui upaya pengajaran, pembiasaan, bimbingan, pengasuhan, pengawasan dan pengembangan potensinya guna mencapai keselarasan dan kesempurnaan hidup di dunia dan akhirat (Jusuf, 2006: 27-28). Menurut Imam Ghazali sebagaimana disebutkan Ibnu Rusn dalam bukunya adalah proses memanusiakan manusia sejak awal kejadiannya sampi akhir hayatnya melalui berbagai ilmu pengetahuan yang disampaikan dalam bentuk pengajaran secara bertahap menjadi tanggung jawab orang tua dan masyarakat sekitarnya (Abidin, 1998: 56).

Menurut Abuddin Nata minimal ada tiga kata kunci yang berhubungan dengan pendidikan Islam, yaitu: al-tarbiyah, alta'lim, dan al-ta'dib. Jika ditelusuri ayatayat al-Qur'an dan matan as-Sunnah secara mendalam dan komprehensif sesungguhnya selain tiga kata tersebut masih terdapat kata-kata lain yang berhubungan dengan pendidikan, yaitu: al-tazkiyah, al-muwa'idzah, al-tafaqquh, al-tilawah, al-tahdzib, al-irsyad, al-tabyin, al-tafakkur, al-ta'aqqul, dan altadabbur (Abuddin, 2010: 2).

Nur Uhbiyati menyatakan Pendidikan Islam adalah suatau system pendidikan yang mencakup seluruh aspek kehidupan yang di butuhkan oleh hamba Allah secara logis (Abdurrahman, 1979: 20). oleh karena itu Islam mempedomani seluruh aspek kehidupan manusia muslim baik di dunia maupun di akhirat (Nur Uhbiyati, 1999: 12). Menurut Ahmad Marimba adalah bimbingan jasmani, rohani berdasarkan hukum-hukum agama Islam menuju kepada terbentuknya kepribadian utama (muslim) (Al-Rasyidin, 1995: 31-32) yaitu kepribadian yang memiliki nilai dan menurut ukuranukuran agama Islam (Ahmad, 1994: 32 dan Nur Uhbiyati, 1998: 5) yang sempurna 
baik yang berkaitan dengan potensi akal, perasaan, maupun perbuatannya (AlRasyidin: 32 dan Abdul Rahman, 2012: 2055).

Pendidikan Islam, menurut Achmadi adalah upaya yang dilakukan untuk membina dan mengembangkan naluri manusia yang dimilikinya baik jasmani maupun rohani menuju terbentuknya manusia seutuhnya sesuai dengan norma Islam (Achmadi, 1992: 20 Ahmad, 1994: 24). Abd al-Rahman al-Nahlawi berpendapat bahwa pendidikan Islam adalah upaya mengembangkan pikiran manusia dan menata tingkah lakunya, emosinya pada seluruh aspek kehidupan agar tujuan yang dikehendaki bisa terealisasi (Abd Raham, t.th: 28).

Karaktristik pendidikan agama Islam menurut Muhaimin adalah (Muhaimin, 2003: 184): 1). Pendidikan Aagama Islam berusaha menjaga akidah peserta didik agar tetap kokoh dalam situasi dan kondisi apapun. 2). Pendidikan Aagama Islam berusaha menjaga dan memelihara ajaran dan nilai-nilai yang tertuang dan yang terkandung dalam Al-quran dan alsunnah serta otentisitas keduanya sebagai sumber utama ajaran Islam. 3). Pendidikan Aagama Islam menonjolkan kesatuan iman, ilmu, dan amal dalam kehidupan keseharian. 4). Pendidikan Aagama Islam berusaha membentuk dan mengembangkan kesalehan individu dan sekaligus kesalehan sosial (Abdul Rahman: 2056). 5). Pendidikan Aagama Islam menjadi landasan moral dan etika dalam pengembangan iptek dan budaya serta aspekaspek kehidupan lainnya. 6). Substansi Pendidikan Aagama Islam mengandung entitas-entitas yang bersifat rasional dan supra rasional. 7). Pendidikan Aagama Islam berusaha menggali, mengembangkan dan mengambil ibrah dari sejarah dan kebudayaan (peradaban) Islam. 8). Dalam beberapa hal Pendidikan Aagama Islam mengandung pemahaman dan penafsiran yang beragam, sehingga memerlukan sikap terbuka dan toleran atau semangat ukhuwah Islamiyah (Muhaimin, 2007: 123). 9). Epistemologi atau teori pengetahuan dalam hal ini pendidikan Islam memiliki keterkaitan dengan pendidikan agama Islam, akan memunculkan pembinaan dan pengoptimalan potensi; penanaman nilainilai Islam dalam jiwa, rasa, dan pikir; serta keserasian dan keseimbangan. Sehingga term akidah, ibadah, dan akhlak atau dengan penjabarannya dengan istilah pengenalan terhadap Allah Swt., potensi dan fungsi manusia serta kajian akhlak dan diterapkan dalam tataran aplikasi berupa cerdas pengetahuan, cerdas sikap dan nilai, serta cerdas dalam tindakan yang diambil dalam kehidupan sehari-hari (berakhlak mulia) (Abdul Rahman: 2058).

\section{PEMBAHASAN \\ Pendidikan Islam Dalam Perspektif Ekonom}

Pendidikan Islam dalam perspektif ekonomi maksudnya adalah pendidikan atau ilmu akan mengentarkan seseorang menjadi kaya, sehingga disebut dengan orang yang punya ekonomi. Rasul saw pernah ditanya perihal ilmu dan ekonomi atau harta, maka Rasul saw menjawab pilih ilmu demikian beliau menceritakan kisah Nabi Sulaiman, Haditsnya : Sulaiman diberi pilihan antara harta, kerajaan, atau ilmu. Maka Sulaiman memilih ilmu. Lalu dengan sebab memilih ilmu (pada akhirnya) ia diberi kerajaan dan harta. (H.R. Ibnu 'Asakir dan ad-Dailami). Rasul saw bersabda barangsiapa yang ingin sukses (bahagia) di dunia akhirat, maka carilah ilmu atau dengan ilmu, sebagaimana hadis Tirmizi :

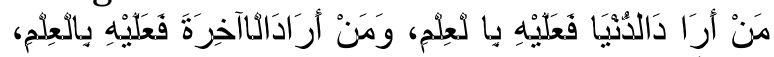

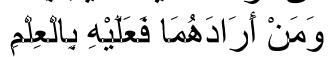

Artinya: Barang siapa yang menghendaki kehidupan dunia maka wajib baginya memiliki ilmu, dan barang siapa yang menghendaki kehidupan Akherat, maka wajib baginya memiliki ilmu, dan barang 
siapa menghendaki keduanya maka wajib baginya memiliki ilmu". (HR. Turmudzi).

Menurut hadis tersebut bahwa kesuksesan seseorang ditentukan oleh ilmu, maka pendidikan menjadi sangat urgen dalam hal meraih kesuksesan dan kebahagiaan. Sehingga Nabi Sulaiman lebih memilih ilmu dari harta, karenanya ilmu mendatangkan harta, namun jangan sampai menuntut ilmu berorientasi utamanya adalah harta atau ekonomi. Maka pendidikan Islam turut andil dalam upaya membuat jalan tengah dengan persoalan ini. Pendidikan Islam yang bertujuan untuk merubah akhlak dan budi pekerti pribadi manusia dalam rangka ibadah kepada Allah dan menuju ketaqwaan kepada Allah. Dalam pandangan ilmu ekonomi, maka pendidikan Islam adalah rangkaian proses pembelajaran dalam mencari pengetahuan untuk mendapatkan kesejahteraan atau ekonomi mapan (harta).

Disiplin ilmu ekonomi mengajarkan pendidikan Islam adalah proses bagaimana cara mencari keuntungan, maka dalam perspektif ekonom pendidikan Islam adalah pendidikan yang dapat mengantarkan kepada meraih keuntungan yang sebanyak-banyaknya dengan pendidikan yang serendahrendahnya, hal ini sesuai dengan konsep ekonomi konvensional, setiap orang melakukan Trade Off, Pengorbanan biaya untuk mendapatkan sesuatu, Orang berpikir secara rasional, Orang tanggap terhadap insentif, Perdagangan Menguntungkan Semua Pihak, Pasar secara umum adalah sarana terbaik untuk mengkoordinasikan kegiatan ekonomi, Pemerintah Kadang Mampu Meningkatkan faktor produksi, Standar hidup negara bergantung pada kemampuan dalam memproduksi barang dan jasa, Harga-harga akan meningkat jika pemerintah mencetak uang dalam jumlah banyak dan Masyarakat menghadapi trade-off jangka pendek antara inflasi dan pengangguran. Kesepuluh prinsif tersebut terangkum dalam satu ungkapan : mengeluarkan modal sekecil-kecilnya unuk mendapatkan laba atau keuntungan sebanyak-banyaknya (Afzalur, 1995: 2 dan Heri, 2004: 91).

Pemahaman seperti ini sudah menjadi term bagi kaum muslim, bahwasanya sekonlah di pendidikan formal seperti pendidikan Islam haruslah berimplikasi kepada lapangan pekerjaan. Maksdunya setelah berpendidikan Islam, bisa kerja apa, dimana, dan dapar gaji berapa?. Karenya pendidikan Islam yang diminati oleh ummat adalah pendidikan Islam yang melahirkan praktisi ekonom yang handal dan siap tempur. Oleh sebab itu tidak heran kalau pendidikan Islam yang seperti ini diminati oleh masyarakat, misalnya jurusan pendidikan Islam keguruan (PAI) baik PAI tingkat MI/SD, MTs/SMP, MA/SMA bahkan tingkat Sarjana. Berikutnya pendidikan Islam keekonomian yang menjadi vaporit adalah jurusan ekonomi Islam, perbankan syariah, bisnis syariah, asuransi syariah, manajemen syariah dan lainya. Dua jurusan inilah yang sangat digemari oleh ummat dalam perjalanan proses pendidikan Islam dewasa ini, hal ini dapat dibuktikan dengan banyaknya institusi yang membuka jurusan tersebut dan membludaknya peserta didiknya (mahasiswa)-nya. Observasil perguruan tinggi Islam di pekanbaru senin tanggal 14 agustus 2017 dapat disimpulkan bahwa dua jurusan tersebut lebih favorit ketimbang yang lainya.

Ilmu ekonomi memandang pendidikan Islam sebagai alat atau sarana untuk mendapatkan keuntungan, tapi ilmu ekonomi Islam menilai pendidikan Islam sebagai jalan ikhtiar untuk mendapatkan keuntungan dalam meraih kesejahteraan ekonomi (harta), dengan jalan yang halal dan berkah, karenanya Islam memandang ekonomi sebagai konsep dasar dalam ubudiyah kepada Allah melalui teori muamalah sebagai 
perwujudan hablum min al-nas (hubungan sosial kepada sesama manusia), baik sosial masyarakat, keluarga maupun ekonomi. Prinsipprinsip dasar ekonomi Islam menurut Umar Chaptra adalah: Prinsip tauhid, tauhid adalah fondasi keimanan Islam. b) Prinsip khilafah. Manusia merupakan khalifah Allah SWT di muka bumi dengan dibekali perangkat baik jasmani maupun rohani untuk dapat berperan secara efektif sebagai khalifah-Nya. Implikasi dari prinsip ini adalah: Persaudaraan yang universal, Sumber daya adalah amanah, Gaya hidup sederhana dan Kebebasan manusia. c) Prinsip keadilan, keadilan adalah salah satu misi utama ajaran Islam, implikasi dari prinsip ini adalah: Pemenuhan kebutuhan pokok manusia, Sumber-sumber pendapatan yang halal dan thayyib, Distribusi pendapatan dan kekayaan yang merata dan Pertumbuhan dan stabilitas (Umer Chapra, 2001: 202206) lihat surah al-Imran ayat 112 :

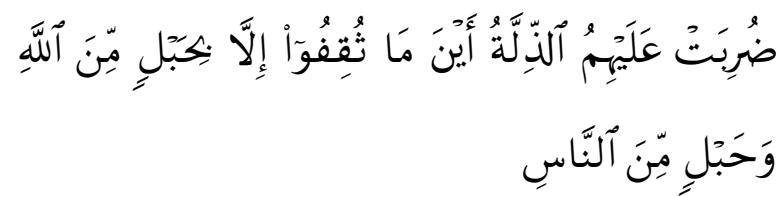

Artinya: Mereka diliputi kehinaan di mana saja mereka berada, kecuali jika mereka berpegang kepada tali (agama) Allah dan tali (perjanjian) dengan manusia[218].

Keterangan : [218] Maksudnya: perlindungan yang ditetapkan Allah dalam Al Quran dan perlindungan yang diberikan oleh pemerintah Islam atas mereka (Depag RI: 94). Wajar Allah mengingatkan manusia akan hal tersebut dalam surah an-Nisa ayat 9 :

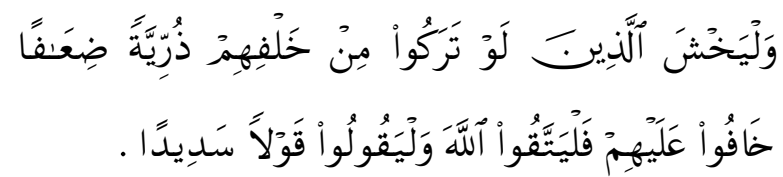

Artinya: Dan hendaklah takut kepada Allah orang-orang yang seandainya meninggalkan dibelakang mereka anakanak yang lemah, yang mereka khawatir terhadap (kesejahteraan) mereka. oleh sebab itu hendaklah mereka bertakwa kepada Allah dan hendaklah mereka mengucapkan perkataan yang benar (Depag RI: 116).

Ayat diatas mendelegasikan bahwa kekhawatiran akan lemahnya ekonomi, ilmu dan iman sepeninggalan kedua orang tuanya, maka hendaknya orang tua merasa takut dan khawatir hal tersebut terjadi. Ini juga mengindikasikan perlunya iman, ilmu dan harta (ekonomi). Kandungan ayat diatas, berpesan agar umat islam menyiapkan generasi penerus yang berkualitas sehingga anak mampu mengaktualisasikan potensinya sebagai bekal kehidupan dimasa mendatang (baik harta (ekononomi (harta), ilmu dan yang terpenting iman) (Quraish, 2002: 355). Asbabul nujul ayat ini tentang harta warisan dan wasiat, juga ada hadis yang menafsirkan ayat tersebut dari riwayat alBukhari dan Muslim :

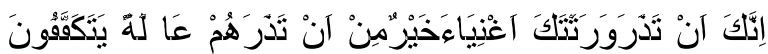
Artinya: Sesunggunya lebih baik meninggalkan ahli warismu dalam keadaan kaya daripada meninggalkan mereka dalam keadaan miskin yang meminta-minta. (HR. Bukhari Muslim).

Pemikiran ekonom berkaitan dengan pendidikan Islam adalah keuntungan dunia saja, jika itu ekonom konvensional, manun ekonom muslim berpikir bahwa pendidikan Islam adalah mencari keuntungan dunia dan akhirat (dalam rizki keuntungan halal, banyak dan berkah), Doa tentang minta rizki berkah :

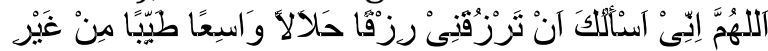

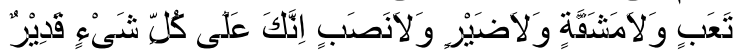
Artinya: Ya Allah, aku minta pada Engkau akan pemberian rizki yang halal, luas, baik tidak tanpa repot dan juga tanpa kemelaratan dan tanpa keberatan sesungguhnya Engkau kuasa atas segala sesuatu (doa).

Menurut Sadono Sukirno pertumbuhan ekonomi diartikan sebagai suatu ukuran kuantitatif yang menggambarkan perkembangan suatu perekonomian dalam suatu tahun tertentu 
apabila dibandingkan dengan tahun sebelumnya (Sukirno, 2006: 27). Menurut Sukirno pendidikan merupakan satu investasi yang sangat berguna untuk pembangunan ekonomi (Sukirno, 2004: 37). Dari dua defenisi tentang pendidikan dan pertumbuhan ekonomi, ternyata memiliki hubungan yang erat. Pertumbuhan ekonomi bisa dicapai dengan memaksimalkan pendidikan, dan ekonomi yang syar'I harus didukung dengan SDM yang religius, sehingga menghasilkan ekonom-ekonom Islami, inilah sebenarnya tujuan pendidikan Islam dalam tinjuan ekonom (Devi, Jurnal 2000-2011: 2-4). Diharapkan pengetahuan tentang pendidikan Islam perspektif ekonom akan menyadarkan para pelaku ekonomi muslim untuk hijrah meninggalkan system dan prilaku transaki ribawi yang tidak berlandaskan asas ekonomi yang berkeadilan dan berketuhanan. Hal ini sesuai dengan silasila pancasila sebagai falsafah Negara Indonesia (ekonomi pancasila) era baru system ekonomi Islam. Ekonomi pancasila sebagai ideologi alternatif yang operasionalisasi konstitusionalnya dituangkan dalam UUD 1945 hendaknya kemudian kita jadikan landasan ideologi dalam membangun kesejahteraan dan keadilan sosial, karena inilah pilihan jalan lurus bagi kita yang saat ini membangun hampir tanpa pijakan ideology (Mubyarto, 2004: 10). Prinsip demokrasi ekonomi ini terjelma dalam UUD 45, pasal 23, 27, 33, dan 34. Untuk penjelasan lebih lanjut tentang hal ini (Emil Salim, Kompas, 30 Juni 1966 dan Widjojo: 130-131 dan Elinor, 2009 dan Widjojo: 131-132 dan Arif: 6-8).

\section{Pendidikan Islam Dalam Perspektif Filosof}

Pendidikan Islam dalam perspektif filosof artinya pendidikan Islam ditinjau dari filsafat ilmu, filsafat pendidikan Islam dan filsafat sufi. Secara sederhana bahwa pendidikan Islam menurut filosof tidak hanya mencerdaskan akal dan pikiran, namun intinya adalah mencerdaskan hati dan jiwa. Sehingga ilmu yang didapat dalam pendidikan Islam tidak hanya di tataran hujjah dan debat, melainkan masuk ke relung jiwa yang menjadikan mudah dan indah serta ringan untuk mengamalkanya, dalam rangka mendekatkan diri kepada Allah dan mencari ridhanya dunia kahirat. Rasulullah shallallahu alaihi wasallam bersabda: Barangsiapa yang bertambah ilmunya tapi tidak bertambah hidayahnya, maka dia tidak bertambah dekat kepada Allah melainkan bertambah jauh (alHadis).

Filsafat pendidikan Islam memandang pendidikan Islam itu dalam tiga dimensi nalar logika (Zainal, 2014: 139), pertama, problem utama dalam filsafat pendidikan Islam adalah tidak jelasnya akar ontologis filsafat pendidikan Islam (filsafat tarbiyah) yang bersumberkan dari filsafat (filosof) muslim. Tapi, kajian ontologis jika dikaitkan dengan obyek ilmu pendidikan Islam, maka ilmu dapat dibagi menjadi dua jenis, yaitu ilmu yang bersifat materi (obyek ilmu yang dapat didengar, dilihat, dan dirasakan, misalnya: sains, ekonomi, budaya, dan lain-lain) dan ilmu yang bersifat non-materi (obyek ilmu yang tidak dapat didengar, dilihat ataupun tidak dapat dirasakan, misalnya: alam ruh atau tentang wujud Tuhan). Kedua, filsafat pendidikan memandang bahwa dimensi epistemologis pendidikan Islam, ilmu dibagi ada dua macam, yaitu ilmu kasbi (usaha) /mubasyarah (langsung), Ilmu yang dipelajari di institusi pendidikan maupun secara otodidak dengan cara mempelajarinya atau (ilmu yang diperoleh karena usaha manusia dengan belajar atau pelacakan) dan ilmu ladunni/mukhasyafah (penyingkapan tabir) yaitu ilmu yang diperoleh tanpa upaya manusia tapi langsung diberikan Allah secara langsung sesuai 
kehendaknya). Hadis Abu Nuaim dari Ahmad bin Hambal:

$$
\text { من عمل بما يعلم ورثه الله علم ما لم يعلم }
$$

Artinya: Siapa yang mengamalkan ilmu yang diketahuinya Allah akan memberikan ilmu yang tidak diketahuinya. (HR. Abu Nuaim dari Ahmad bin Hambal).

Didukung dengan al-Qur'an surah alAnkabut ayat 69:

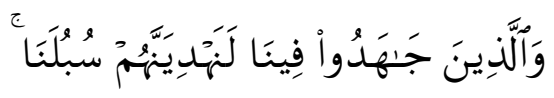

Artinya: Dan orang-orang yang berjihad untuk (mencari keridhaan) kami, benarbenar akan kami tunjukkan kepada mereka jalan-jalan kami (Depag RI: 638).

Selain itu, Islam juga mengakui sumber ilmu yang berasal dari indera, akal, hati, dan wahyu yang semuanya berasal dari Allah. Problem epistemologis pendidikan Islam adanya dikotomi ilmu tidak perlu terjadi, sebab pada dasarnya semua ilmu berasal dari Allah. Ketiga, dimensi aksiologis pendidikan Islam, bahwa ilmu dipandang dari perspektif kebermanfaatan bagi kehidupan manusia dibagi menjadi dua, yaitu ilmu yang bermanfaat langsung untuk kehidupan dunia dan ilmu yang bermanfaat untuk kehidupan di akhirat. Pendidikan Islam (Islam) tidak membedakan antara kebermanfaatan ilmu bagi kehidupan di dunia dan akhirat. Tujuan utama dari pendidikan Islam adalah membentuk etika/kepribadian muslim yang humanis dan religious (Umiarso, 2011: 101 dan Zainal: 138).

Para filosof berpandangan bahwa pendidikan agama adalah sarana menuju ketengan dan mengetahui hakikat diri sendiri (ruh) jiwa dan raga (Poerwantana, 1988: 172). Menurut para filosof dalam banyak karanganya termasuk diantaranya imam Ghazali berpandangan pendidikan Islam itu pada intinya ada pada tiga dimensi, yaitu : ilmu, hati dan ketuhanan (Allah) (A. Mustofa, 1999: 215). Dari imam Ghazali punya pandangan tersendiri dalam menilai pendidikan Islam. Permulaan pendidikan dasar menurutnya adalah pendidikan keluarga, lalu pendidikan menengah adalah lingkungan masyarakat dan pendidikan atas analisis adalah pendidikan agama Islam yang mengacu pada kesatuan antara ilmu, iman dan hati (jiwa atau ruh), sehingga menjadi insane kamil (Fatiyah, terj. Said Agil,1993; 18 dan Alwizar, 2015: 136).

Seorang sufi yang juhud dan filosof yang cerdas dari keturunan Nabi sekaligus menantu dan sepupu Nabi adalah sahabat Ali bin Abi Thalib, beliau satu dari Khulafaur Rasyidin (para pemimpin yang diberi petunjuk) yang terkenal sebagai seorang miskin di antara para sahabat Rasulullah saw, meskipun demikian sahabat Ali bin Abi Thalib adalah sahabat yang pandai, cerdas, dan berilmu (Muhammad, t.th: 4). Hal ini dibuktikan dari sabda Rasulullah saw sebagaimana berikut ini :

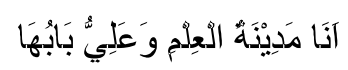

Artinya: Aku adalah kota ilmu sedangkan Ali adalah pintunya.

Hadits ini diriwayatkan oleh atTurmudzy dari hadits 'Ali, diriwayatkan oleh al-Hakim di dalam kitab al-Mustadrak dari hadits Ibn 'Abbas. Ia mengomentari, "Hadits Shahih." Al-Hafizh Abu Sa'id al"Alaa iy berkata, "Yang benar, bahwa ia hadits Hasan bila dilihat dari jalurjalurnya, tidak shahih dan juga tidak Dla'if apalagi dikatakan Mawdlu' (palsu).

Setelah Rasulullah saw wafat dan tiga Khalifah Khulafaur Rasyidin telah berlalu. Tiba saatnya pemerintahan khalifah ditangan Ali bin Abi Thalib. Pada masa ini, timbul banyak konflik internal yang menimbulkan perselisihan antara kaum muslimin. Lahirlah idiologi khawarij, ketika mereka mendengar hadist Rasulullah saw di atas, mereka sangat iri dan dengki. sehingga para pembesar Khawarij berkumpul dan rapat (Muhammad: 4). Mereka mengatakan "Kita akan bertanya kepada Ali bin Abi Thalib satu pertanyaan dan bagaimana ia akan menjawab. Jika ia menjawab dengan jawaban yang berbeda maka pantaslah 
kita mengakui bahwa ia seorang yang pandai (filosof). Maka satu persatu dari kaum khawarij mendatangi Ali bin Abi Thalib sesuai hasil rapat (Muhammad: 4).

Orang Khawarij Pertama : Beberapa waktu kemudian datanglah seorang dari golongan mereka kepada khalifah Ali bin Abi Tholib dan bertanya "Wahai Ali, mana yang lebih utama ilmu atau harta ?". Khalifah Ali bin Abi Thalib pun menjawab "Ilmu lebih utama daripada harta". Kemudian orang tersebut bertanya lagi "Apa alasannya ?". Khalifah Ali bin Abi Thalib pun menjawab "Ilmu adalah warisan para nabi, sedangkan harta adalah warisan dari Qorun, Syaddad, Fir'aun dan sebagainya.". Mendengar jawaban tersebut penanya pertama pun segera pergi dengan puas atas jawaban tersebut (Muhammad: 4).

Orang Khawarij Kedua : Kemudian datang lagi orang khawarij lainnya dan bertanya kepada Khalifah Ali bin Abi Tholib "Wahai Ali, mana yang lebih utama ilmu atau harta ?". Khalifah Ali bin Abi Tholib pun menjawab "Ilmu lebih utama daripada harta". Kemudian orang tersebut bertanya lagi "Apa alasannya ?". Khalifah Ali bin Abi Tholib pun menjawab "Ilmu bisa menjagamu. Sedangkan harta, kamulah yang menjaganya.". Mendengar jawaban tersebut penanya kedua pun segera pergi dengan puas (Muhammad: 45).

Orang Khawarij Ketiga : Kemudian datang lagi orang khawarij lainnya dan bertanya kepada Khalifah Ali bin Abi Tholib seperti pertanyaan orang pertama dan kedua. Khalifah Ali bin Abi Tholib pun menjawab "Ilmu lebih utama daripada harta". Kemudian orang tersebut bertanya lagi "Apa alasannya ?". Khalifah Ali bin Abi Tholib pun menjawab "Orang yang mempunyai harta, ia memiliki banyak musuh. Sedangkan orang yang berilmu, ia memiliki banyak teman.". Mendengar jawaban tersebut penanya ketiga pun segera pergi (Muhammad: 4-5).

\section{Orang Khawarij Keempat :} Kemudian datang lagi orang khawarij lainnya dan bertanya kepada Khalifah Ali bin Abi Tholib "Wahai Ali, mana yang lebih utama ilmu atau harta ?". Khalifah Ali bin Abi Tholib pun menjawab "Ilmu lebih utama daripada harta". Kemudian orang tersebut bertanya lagi "Apa alasannya ?". Khalifah Ali bin Abi Tholib pun menjawab "Jika kamu membelanjakan harta, maka harta itu akan berkurang. Tetapi jika kamu membelanjakan ilmu, maka ilmu itu akan semakin bertambah". Mendengar jawaban tersebut penanya keempat pun segera pergi (Muhammad: 4-5).

Orang Khawarij Kelima : Kemudian datang lagi orang khawarij lainnya dan bertanya kepada Khalifah Ali bin Abi Tholib "Wahai Ali, mana yang lebih utama ilmu atau harta ?". Khalifah Ali bin Abi Tholib pun menjawab "Ilmu lebih utama daripada harta". Kemudian orang tersebut bertanya lagi "Apa alasannya ?". Khalifah Ali bin Abi Tholib pun menjawab "Pemilik harta dipanggil dengan sebutan kikir dan pelit. Sedangkan pemilik ilmu dipanggil dengan sebutan mulya dan agung.". Mendengar jawaban tersebut penanya kelima pun segera pergi.

Orang Khawarij Keenam : Kemudian datang lagi orang khawarij lainnya dan bertanya kepada Khalifah Ali bin Abi Tholib "Wahai Ali, mana yang lebih utama ilmu atau harta ?". Khalifah Ali bin Abi Tholib pun menjawab "Ilmu lebih utama daripada harta". Kemudian orang tersebut bertanya lagi "Apa alasannya ?". Khalifah Ali bin Abi Tholib pun menjawab "Harta selalu dijaga dari seorang pencuri. Tetapi ilmu tidak pernah dijaga dari seorang pencuri". Mendengar jawaban tersebut penanya keenam pun segera pergi (Muhammad: 4-6).

Orang Khawarij Ketujuh : Kemudian datang lagi orang khawarij lainnya dan bertanya kepada Khalifah Ali bin Abi Tholib "Wahai Ali, mana yang lebih utama ilmu atau harta ?". Khalifah Ali bin Abi Tholib pun menjawab "Ilmu lebih utama 
daripada harta". Kemudian orang tersebut bertanya lagi "Apa alasannya ?". Khalifah Ali bin Abi Tholib pun menjawab "Pemilik harta akan dihisab dan diperhitungkan atas hartanya kelak di hari kiamat. Sedangkan pemilik ilmu, ia akan mendapat syafa'at di hari kiamat.". Mendengar jawaban tersebut penanya ketujuh pun segera pergi (Muhammad: 56).

Orang Khawarij Kedelapan : Kemudian datang lagi orang khawarij lainnya dan bertanya kepada Khalifah Ali bin Abi Tholib "Wahai Ali, mana yang lebih utama ilmu atau harta ?". Khalifah Ali bin Abi Tholib pun menjawab "Ilmu lebih utama daripada harta". Kemudian orang tersebut bertanya lagi "Apa alasannya ?". Khalifah Ali bin Abi Tholib pun menjawab "Harta akan habis sepanjang masa dan hancur sesuai perjalanan waktu. Sedangkan ilmu tidak pernah habis dan tidak akan hancur.". Mendengar jawaban tersebut penanya kedelapan pun segera pergi (Muhammad: 5-6).

Orang Khawarij Kesembilan : Kemudian datang lagi orang khawarij lainnya dan bertanya kepada Khalifah Ali bin Abi Tholib "Wahai Ali, mana yang lebih utama ilmu atau harta ?". Khalifah Ali bin Abi Tholib pun menjawab "Ilmu lebih utama daripada harta". Kemudian orang tersebut bertanya lagi "Apa alasannya ?". Khalifah Ali bin Abi Tholib pun menjawab "Harta menjadikan hati keras. Sedangkan ilmu dapat menyinari hati.". Mendengar jawaban tersebut penanya kesembilan pun segera pergi (Muhammad: 5-6).

Orang Khawarij Kesepuluh : Kemudian datang lagi orang khawarij lainnya dan bertanya kepada Khalifah Ali bin Abi Tholib "Wahai Ali, mana yang lebih utama ilmu atau harta ?". Khalifah Ali bin Abi Tholib pun menjawab "Ilmu lebih utama daripada harta". Kemudian orang tersebut bertanya lagi "Apa alasannya ?". Khalifah Ali bin Abi Tholib pun menjawab "Harta membuat pemiliknya merasa seolah seperti tuhan karena harta yang dimilikinya. Sedangkan pemilik ilmu merasa ia adalah seorang hamba. Jika kamu semua bertanya kepadaku tentang hal ini, maka selama aku hidup, aku akan menjawabnya dengan jawaban yang berbeda.". Mendengar jawaban tersebut penanya kesembilan pun segera pergi (Muhammad: 6-7).

Mendengar semua jawaban berbeda dari Khalifah Ali bin Abi Thalib, mereka merasa puas dan sadar bahwa apa yang sudah mereka lakukan adalah salah. Kemudian, mereka menemui Khalifah Ali bin Abi Thalib dan memasrahkan diri kepada Beliau untuk mengabdi sebagai rakyat. Mereka semua mengakui akan kecerdasan dan kontruksi filosof yang kokoh dari sosok khalifah Ali bin Abi Thalib. Pendidikan Islam ditinjau dari filosof adalah pendidikan yang mencerdaskan rohani sekaligus pendidikan yang berbasis kondisional sesuai dengan tatanan sosiologis pendidikan Islam dalam bingkai maqashid pendidikan Islam itu sendiri.

\section{Analisis Paradigma Pendidikan Barat Dan Timur}

Pradigma aliran pendidikan barat diantaranya William Stern berpandangan bahwa antara heredity dan meliau ada saling keterkaitan memberi pengaruh dalam pertumbuhan dan perkembangan manusia (Ngalim, 1995: 60). Secara kodrati manusia, telah dibekali dengan bakat atau potensi. Akan tetapi, untuk berkembang lebih baik perlu adanya pengaruh dari luar berupa tuntunan dan bimbingan melalui pendidikan (Jalaluddin, 1997: 161).

Pradigma aliran pendidikan timur tengah misalnya Imam al-Gazali, berpendapat bahwa anak yang lahir telah membawa fitrahnya sendiri, kecenderungan-kecenderungan serta warisan dari orang tuanya. Kesemuanya itu perlu diberi pendidikan. Jika ia bengkok maka harus diluruskan, jika salah dibenarkan dan jika sudah benar maka 
diarahkan kepada pengembangannya (Muhammad, 1975: 255 dan Zainuddin, 1991: 67).

Dua konsep pendidikan dari pespektif ekonom dan filosof pada dasarnya adalah jelmaan dari paradigma pendidikan barat dan timur tengah. Paradigma pendidikan barat lebih mengajarkan idiologi sekuler, kavitalis, sosialis dan materialis. Sedangkan paradigma pendidikan timur tengah lebih mengedepankan integralis dari idiologi diatas dengan bingkai religi Islami (syariat Islam). Namun kajian ini perlu dipilahpilah, paradigma perspektip ekonom konvensional (barat) itu benar adanya, semua umat muslim merasakanya dan menyadari akan hal itu. Akan tetapi paradigma ekonomi Islam (ekonom muslim) idiologi tersebut sudah melebur menjadi paradigma leburan dari ke empatnya, yaitu perspektif keIslaman sesuai tuntunan syariat Islam, dengan konsep keadilan dan kebersamaan.

Menyebarnya keIslaman di seluruh dunia, menjadi doktrin tersendiri terhadap pemeluknya di Negara selain timur tengah, sehingga kaum muslim dari etnis diluar timur tengah mengalami perubahan dalam logika nalar filsafatnya. Demikian juga dengan paradigma pendidikan di barat dan erofa juga mengalami pergeseran yang cukup signifikan, terutama mereka yang mencoba mempelajari keIslaman secara meraton. Sehingga kontruksi berpikir paradigma filsafat cenderung lembut dinamis sesuai dengan nalarnya yang sudah terkontaminasi dengan ajaran ketuhanan yaitu syariat Islam. Karena itu, paradigma pendidikan barat sudah memasukkan nilai-nilai rohani dan jiwa dalam mendefenisikan dan menkonsep tujuan dari pendidikan tersebut. Hal ini bisa di lihat dalam buku-buku karangan mereka yang berkaitan denngan filasafat pendidikan dan tujuan pendidikan.

Sedangkan paradigma pendidikan timur tengah lebih mengedapankan nilai- nilai agama sesuai dengan tuntunan Islam, yaitu menyempurnakan akhlak dan menjadi insan kamil. Kedua paradigma barat dan timur ini, sekiranya di integralkan akan menjadi raksasa dalam sebuah teori atau konsep dalam menggapai kesejahteraan dan keadilan serta kebahagiaan dunia akhirat. Maksudnya pendidikan Islam perlu ekonomi dan pendidikan harus melahirkan ekonom-ekonom praktis. Sehingga nilai-nilai pendidikan Islam mendapatkan jati dirinya mensejahterakan ummat dan melahirkan ilmuan-ilmuan yang cerdas lahir dan bathin. Hal ini akan menjadi bukti nya akan kebenaran ayat-ayat wahyu alQur'an dan sunah Rasul saw serta mutiara hikmah para sahabat dan alim ulama tentang keutamaan ilmu dari harta, seperti surah al-Mujadalah ayat 11 , alAnkabut ayat 69 serta hadis Nabi tentang Ilmu juga mutiara hikmah Ali bin Abi Thalib tentang keutamaan ilmu dari harta. Diharapkan umat dalam menjalani pendidikan Islam tidak terlalu berorientasi pada nilai ekonomi saja, akan tetapi bertujuan mencari ilmu sebanyakbanyaknya sebagai bekal dalam menjalani kehidupan sesuai hadis riwayat Tirmizi diatas, bahwasanya kebahagiaan dunia akhirat diperoleh dengan ilmu, sehingga cerdas intelektual dan emosional serta spiritual.

\section{PENUTUP}

Pendidikan Islam dalam perspektif ekonomi maksudnya adalah pendidikan atau ilmu akan mengentarkan seseorang menjadi kaya, sehingga disebut dengan orang yang punya ekonomi. Rasul saw pernah ditanya perihal ilmu dan ekonomi atau harta, maka Rasul saw menjawab pilih ilmu demikian beliau menceritakan kisah Nabi Sulaiman. Haditsnya : Sulaiman diberi pilihan antara harta, kerajaan, atau ilmu. Maka Sulaiman memilih ilmu. Lalu dengan sebab memilih ilmu (pada akhirnya) ia diberi kerajaan dan harta. 
(H.R. Ibnu 'Asakir dan ad-Dailami). Rasul saw bersabda barangsiapa yang ingin sukses (bahagia) di dunia akhirat, maka carilah ilmu atau dengan ilmu. Hadis Tirmizi yang artinya: Barang siapa yang menghendaki kehidupan dunia maka wajib baginya memiliki ilmu, dan barang siapa yang menghendaki kehidupan Akherat, maka wajib baginya memiliki ilmu, dan barang siapa menghendaki keduanya maka wajib baginya memiliki ilmu". (HR. Turmudzi). Menurut hadis tersebut bahwa kesuksesan seseorang ditentukan oleh ilmu, maka pendidikan menjadi sangat urgen dalam hal meraih kesuksesan dan kebahagiaan. Sehingga Nabi Sulaiman lebih memilih ilmu dari harta.

Pendidikan Islam dalam perspektif filosof artinya pendidikan Islam ditinjau dari filsafat ilmu, filsafat pendidikan Islam dan filsafat sufi. Secara sederhana bahwa pendidikan Islam menurut filosof tidak hanya mencerdaskan akal dan pikiran, namun intinya adalah mencerdaskan hati dan jiwa. Sehingga ilmu yang didapat dalam pendidikan Islam tidak hanya di tataran hujjah dan debat, melainkan masuk ke relung jiwa yang menjadikan mudah dan indah serta ringan untuk mengamalkanya, dalam rangka mendekatkan diri kepada Allah dan mencari ridhanya dunia kahirat.

Dua konsep pendidikan dari pespektif ekonom dan filosof pada dasarnya adalah jelmaan dari paradigma pendidikan barat dan timur tengah. Paradigma pendidikan barat lebih mengajarkan idiologi sekuler, kavitalis, sosialis dan materialis. Sedangkan paradigma pendidikan timur tengah lebih mengedepankan integralis dari idiologi diatas dengan bingkai religi Islami (syariat Islam). Paradigma pendidikan di barat dan erofa juga mengalami pergeseran yang cukup signifikan, terutama mereka yang mencoba mempelajari keIslaman secara meraton. Sedangkan paradigma pendidikan timur tengah lebih mengedapankan nilai-nilai agama sesuai dengan tuntunan Islam, yaitu menyempurnakan akhlak dan menjadi insan kamil. Kedua paradigma barat dan timur ini, sekiranya di integralkan akan menjadi raksasa dalam sebuah teori atau konsep dalam menggapai kesejahteraan dan keadilan serta kebahagiaan dunia akhirat. Pendidikan Islam berorientasi pada nilai ekonomi saja, akan tetapi bertujuan mencari ilmu sebanyakbanyaknya sebagai bekal dalam menjalani kehidupan sesuai hadis dan kebahagiaan dunia akhirat diperoleh dengan kecerdasan intelektual dan emosional serta spiritual.[] 


\section{DAFTAR RUJUKAN}

Achmadi. Islam sebagai Paradigma Ilmu Pendidikan, Yogyakarta: Aditya Media, 1992.

Affan, Afraniati. Filsafat Logika, Padang: Azka Padang, 2002.

Al-Abrasyi, Muhammad Atiyah. alTarbiyyah al-Islamiyyah wa Falasifatuha, Cet. III, Isa al-Babiy alHalbiy wa Syurakahu, 1975.

Al-Nahlawi. Abdurrahman. Ushul alTarbiyahal-Islamiyah wa Asalibiha, Damaskus: Dar al Fikr, 1979.

Al-Rasyidin dan H. Samsul Nizar, Filsafat Pendidikan Islam, Jakarta: Ciputat Press, 1995.

Alwizar, Pemikiran Pendidikan Al-Ghazali, Jurnal Potensia vol. 14 Edisi 1 Januari-Juni 2015.

Arifin, Zainal. "Pendidikan Islam Dalam Perspektif

Filsafat

Ilmu." Ta'dib 19.01 (2014): 123-142.

Budiarti, Devi, and Yoyok Seosatyo. "Pengaruh Tingkat Pendidikan Terhadap Pertumbuhan Ekonomi Di Kabupaten Mojokerto Tahun 20002011." Jurnal Pendidikan Ekonomi (JUPE) 2.1 (2014).

Bugin, Burhan. Penelitian Kualitatif; Komunikasi, Ekonomi, Kebijakan Publik dan Ilmu Sosial Lainnya, Jakarta: Kencana, 2008.

Daradjat, Zakiah. Ilmu Pendidikan Islam, Jakarta: Bumi Aksara, 1992.

Daud, Wan. Filsafat dan Praktik Pendidikan Islam Syed M. Naquib alAttas, Bandung: Mizan, 2003.

Departemen Agama RI, Al-Qur'an dan Terjemahanya, Semarang: Toha Putra, 2005.

Dewantara, Ki Hadjar. Karja I, Pendidikan, Jogjakarta: Pertjetakan Taman Siswa, 1962.

Dewantara, Ki Hadjar. Masalah Kebudayaan, Jogjakarta: Pertjetakan Taman Siswa, 1954.
Djamarah, Syaiful Bahri. Guru dan Anak Didik dalam Interaksi Edukatif, Jakarta: Rineka Cipta, 2000.

Djatnika, A. Rachmat. Sistem Ethika Islam (Akhlak Mulia), Jakarta: Pustaka Panjimas, 1996.

Djumhur, Danasaputra I. Sejarah Pendidikan, Bandung: Pustaka Ilmu, 1876.

Hadi, Edwar. Urgensi Belajar Dalam Tafsir Al-Mishbah Surat Al-'Alaqayat 1-5 Dan Implikasinya Terhadap Metode Pendidikan Islam, Yogyakarta: Jurusan Kependidikan Islam Fakultas Ilmu Tarbiyah Dan Keguruanuniversitas Islam Negeri Sunan Kalijaga, 2014.

Harjo, Raja Mudya. Pengantar Pendidikan, Jakarta: Raja Wali Pers, 2001.

Heri Sudarsono, Konsep Ekonomi Islam, Yogyakarta: Ekonosia, 2004.

Jalaluddin dan Abdullah Idi, Filsafat Pendidikan, Jakarta: Gaya Media Pratama, 1997.

Kriyantono, Rachmat, Teknik Praktis Riset Komunikasi, Jakarta: Kencana Prenada Media Grup, 2010.

Langgulung, Hasan. Asas-asas Pendidikan Islam, Jakarta: Pustaka Al-Husna, 1992.

Langgulung, Hasan. Pendidikan Islam Menghadapi abad 21, Jakarta: Pustaka AlHusna, 1988.

Meleong, Lexy J.Metode Penelitian Kualitatif, Bandung: Remaja Rosda Karya, 2011.

Mubyarto (Ed.), Menggugat Ketimpangan dan Ketidakadilan Ekonomi Nasional: Mengurai Benang Kusut Subsidi BBM dan Defisit APBN, Yogyakarta: Aditya Media dan PUSTEP UGM, 2004.

Mudzakkir, Jusuf. Abdul Mujib, Ilmu Pendidikan Islam, Jakarta: Kencana Prenada Media, 2006.

Muhaimin, Pengembangan Kurikulum Pendidikan Agama Islam, Jakarta: Rajawali Press, 2007.

Muhaimin, Wacana Pengembangan Pendidikan Islam, Surabaya: Pusat 
Studi Agama, Politik dan Masyarakat, 2003.

Muhajir, Noeng. Metodologi Penelitian Kuantitatif, Yogyakarta: Rake Sarasin, 1996.

Muhammad bin Abi Baka, al-Mawaidzul al-Ush'furiyyah, Bimakna ala pesantren, tt.

Mustofa, A. Filsafat Islam, Bandung: Pustaka Setia, 1999.

Nata, Abuddin. Ilmu Pendidikan Islam (Jakarta : Kencana, 2010)

Nata, Abuddin. Paradigma Pendidikan Islam (Kapita Selekta Pendidikan Islam), Jakarta: Grasindo, 2001.

Nawawi, Hadari. Organisasi Sekolah dan Pengelolaan kelas sebagai Lembaga Pendidikan, Jakarta: Gunung Agung, 1982.

Ostrom, Elinor. Governing The Commons. Rhe Evolution of Innstutuions for Collective Action. Cambridge University Press. 1990. Profesor Ilmu Politik, Peraih Nobel Ekonomi 2009.

Poerwantana, dkk, Seluk Beluk Filsafat Islam, Bandung: Rosda, 1988.

Poerwardarminta, Kamus Besar Bahasa Indonesia, Jakarta: Balai Pustaka, 1991.

Purwanto, M. Ngalim. Ilmu Pendidikan Teoriris dan Praktis, Edisi II, Cet. VIII; Bandung: Remaja Rosdakarya, 1995.

Pusat Bahasa Departemen Pendidikan Nasional, Kamus Besar Bahasa Indonesia, Jakarta: Balai Pustaka, 2001.

Rahman, Abdul. "Pendidikan Agama Islam dan Pendidikan Islam-Tinjauan Epistemologi dan Isi-Materi." Jurnal Eksis 8.1 (2012).

Rahman, Fazlur. Economic Doctrine of Islam, Alih Bahasa, Soeroyo dan Nastangin, Doktrin Ekonomi Islam, Yogyakarta: Dana Bakti Wakaf, 1995.

Rusn, Abidin Ibnu. Pemikiran al-Ghazali Tentang Pendidikan, Yogyakarta : Pustaka Pelajar, 1998.
Salim, Emil. Sistem Ekonomi Pancasila, Kompas, 30 Juni 1966.

Shihab. M. Quraish. Tafsir Al-Misbah Pesan, Kesan dan Keserasian Al-Qur'an, Jakarta: Lentera Hati, 2002.

Sindhunata (ed.), Menjadi Generasi PascaIndonesia, Yogyakarta: Kanisius, 1999.

Sugiono, Memahami Penelitian Kualitatif, Bandung: ALFABETA, 2005.

Sukirno, Sadono. Ekonomi Pembangunan: Proses, Masalah, Dan Dasar Kebijakan, Jakarta: Kencana, 2006.

Sukirno, Sadono. Makroekonomi Teori pengantar (Jakarta: PT. Raja Grafindo persada, 2004)

Sulaiman, Fatiyah Hasan. Aliran-Aliran dalam Pendidikan (Studi Tentang Aliran Pendidikan Menurut AlGhazali, terj. Agil Husain AlMunawwar dan Hadri Hasan, dari Judul Asli, Kitab Mazahib fi alTarbiyyah Bahtsun fi al-Mazahib alTarbaw Ind al-Ghazali, Semarang: Toha Putra, 1993.

Sumaatmadja, Nursid. Pendidikan Pemanusiaan Manusia Manusiawi, Bandung: Alfabeta, 2002.

Syukur Kholil, Metodologi penelitian, (Bandung: Citapusaka Media, 2006)

Tafsir, Ahmad. Ilmu Pendidikan Dalam Perspektif Islam, Bandung: PT. Remaja Rosdakarya, 1994.

Tilaar, H.A.R. Ed. Pendidikan Kebudayaan Dan Masyarakat Madani Indonesia, Bandung: Remaja Rosdakarya, 1999.

Uhbiyati, Nur. Ilmu Pendidikan Islam Bandung : Pustaka Setia, 1998.

Uhbiyati, Nur. Ilmu Pendidikan Islam, Bandung: Pustaka Setia, 1999.

Umar, Husein. Metode Riset Komunikasi Organisasi: Sebuah Pendekatan Kuantitatif Dilengkapi dengan Contoh Proposal dan Hasil Riset Komunikasi Organisasi, Jakarta: Gramedia Pustaka Utama, 2002.

Umer Chapra, The Future of Economics, (terj), Jakarta:Gema Insani Press, 2001. 
Umiarso dan Sri Minarti Baharuddin, Dikotomi Pendidikan Islam Historisitas dan Implikasi pada Masyarakat Islam, Bandung: Remaja Rosdakarya, 2011.

Yasunari, Bartolomeus Samho dan Oscar. Konsep Pendidikan Ki Hadjar Dewantara Dan Tantangantantangan Implementasinya Di Indonesia Dewasa Ini, Bandung: Lembaga Penelitian Dan Pengabdian Kepada Masyarakat Universitas Katolik Parahyangan, 2010.

Zainuddin, Seluk Beluk Pendidikan dari alGazali, Jakarta: Bumi Aksara, 1991.

Zeid, Mestika. Metode Penelitian Kepustakaan, Jakarta: Yayasan Obor Indonesia, 2004. 